\title{
Factors Influencing Vancomycin Loading Dose for Hospitalized Hemodialysis Patients: Prospective Observational Cohort Study
}

\author{
Wasim S El Nekidy, Maher M El-Masri, Greg S Umstead, and Michelle Dehoorne-Smith
}

\begin{abstract}
Background: The increasing use of vancomycin to treat methicillinresistant Staphylococcus aureus (MRSA) has resulted in reduced susceptibility of MRSA to this drug. It is important to optimize vancomycin dosing in patients who are undergoing hemodialysis to attain a pre-hemodialysis serum concentration sufficient to eradicate MRSA, in accordance with recent guideline recommendations.
\end{abstract}

Objectives: To establish the optimal strategy for vancomycin loading dose in patients undergoing hemodialysis and to explore the determinants of pre-hemodialysis serum concentration of vancomycin measured in these patients.

Methods: A prospective observational cohort study was conducted between January and June 2010. Eligible participants were adults with established stage 5 chronic kidney disease who were undergoing inpatient hemodialysis. Data were collected on loading dose administered, body weight, serum concentration of vancomycin before the subsequent hemodialysis session (pre-hemodialysis concentration), and time between end of vancomycin infusion and measurement of pre-hemodialysis serum concentration. Multivariate stepwise linear regression was performed to examine independent associations between variables and measured pre-hemodialysis serum concentration of vancomycin.

Results: Eighty-one patients were included in the study. Of 24 patients who achieved the recommended pre-hemodialysis serum concentration of vancomycin (15-20 mg/L), 14 had a loading dose between 15 and $20 \mathrm{mg} / \mathrm{kg}$. Further analysis suggested that the pre-hemodialysis serum concentration of vancomycin was independently associated with weightbased loading dose $(\mathrm{mg} / \mathrm{kg})(\beta=0.293, p=0.003)$, age $(\beta=-0.358$, $p<0.001$ ), and time between administration of the loading dose and initiation of hemodialysis $(~(\beta=-0.247, p=0.011)$.

Conclusions: The findings of this study indicate that a loading dose of $15-20 \mathrm{mg} / \mathrm{kg}$ (actual body weight) is likely to yield an optimal pre-hemodialysis serum concentration at a median elapsed time of $24 \mathrm{~h}$. In addition to loading dose, patient age and time between administration of the loading dose and initiation of hemodialysis also influenced the pre-hemodialysis serum concentration of the drug.

Key words: vancomycin, hemodialysis, dosing

\section{RÉSUMÉ}

Contexte : : L'utilisation accrue de vancomycine pour traiter les infections à Staphylococcus aureus résistant à la méthicilline (SARM) a entraîné une réduction de la sensibilité du SARM à ce médicament. Il est important d'optimiser la posologie de la vancomycine chez les patients hémodialysés pour obtenir une concentration sérique préalable à l'hémodialyse suffisante pour éradiquer le SARM, conformément aux recommandations récentes des lignes directrices.

Objectifs : Établir la dose d'attaque optimale de la vancomycine chez les patients subissant une hémodialyse et examiner les déterminants de la concentration sérique de la vancomycine préalable à l'hémodialyse chez ces patients.

Méthodes : Une étude de cohorte observationnelle prospective a été menée entre janvier et juin 2010. Les patients admissibles étaient des adultes atteints d'une néphropathie chronique de stade 5 subissant une hémodialyse en milieu hospitalier. Les données ont été recueillies pour la dose d'attaque administrée, le poids corporel, la concentration sérique de vancomycine avant la séance d'hémodialyse subséquente (concentration préalable à l'hémodialyse) et le temps entre la fin de la perfusion de la vancomycine et la mesure de la concentration sérique préalable à l'hémodialyse. Une analyse par régression linéaire séquentielle a été réalisée pour examiner les associations indépendantes entre les variables et la concentration sérique de vancomycine mesurée avant l'hémodialyse.

Résultats : Au total, 81 patients ont été admis à l'étude. Des 24 patients qui ont obtenu la concentration sérique de vancomycine recommandée préalablement à l'hémodialyse (15-20 mg/L), 14 ont reçu une dose d'attaque de 15 à $20 \mathrm{mg} / \mathrm{kg}$. D'autres analyses ont suggéré que la concentration sérique de vancomycine préalable à l'hémodialyse était associée de façon indépendante à la dose d'attaque fondée sur le poids $(\mathrm{mg} / \mathrm{kg})(\beta=0,293, p=0,003)$, à l'âge $(\beta=-0,358, p<0,001)$ et au temps écoulé entre l'administration de la dose d'attaque et le début de l'hémodialyse ( $B=-0,247, p=0,011)$.

Conclusions : Les résultats de cette étude montrent qu'une dose d'attaque de 15 à $20 \mathrm{mg} / \mathrm{kg}$ (poids corporel réel) est susceptible de produire une concentration sérique optimale de vancomycine préalablement à l'hémodialyse dans un temps médian de $24 \mathrm{~h}$. Outre la dose d'attaque, l'âge du patient et le temps écoulé entre l'administration de la dose d'attaque et le début de l'hémodialyse ont également influencé la concentration sérique de vancomycine préalable à l'hémodialyse.

Mots clés : vancomycine, hémodialyse, posologie

[Traduction par l'éditeur] 


\section{INTRODUCTION}

$\mathrm{V}$

ancomycin has been used to treat infection with gram-positive bacteria, including methicillin-resistant Staphylococcus aureus (MRSA), for more than 50 years. ${ }^{1-5}$ Among patients with stage 5 chronic kidney disease who are undergoing hemodialysis, infections are the second most common cause of death, and vancomycin is considered one of the main options for treating infections in these patients. ${ }^{4.6} \mathrm{In}$ addition, S. aureus infections account for approximately $39 \%$ of all cases of catheter-related bacteremia among patients undergoing hemodialysis, ${ }^{1}$ and MRSA strains account for up to $60 \%$ of all S. aureus infections. ${ }^{7.8}$

The pharmacokinetics of vancomycin are characterized by a distribution phase and an elimination phase. In patients with normal kidney function, the half-lives of the distribution and elimination phases are about 0.5 to $1 \mathrm{~h}$ and 3 to $10 \mathrm{~h}$, respectively. ${ }^{2,3}$ However, the half-life of vancomycin in patients with stage 5 chronic kidney disease can reach $180 \mathrm{~h}$ or more. ${ }^{1,9-11}$ Therefore, given that approximately $90 \%$ of vancomycin clearance occurs through the kidneys, vancomycin dosing should be carefully calculated for patients with advanced kidney disease. ${ }^{1,49}$ Furthermore, whereas the volume of distribution for vancomycin in patients with normal kidney function ranges between 0.4 and $1.0 \mathrm{~L} / \mathrm{kg}$, it ranges from 0.72 to $0.9 \mathrm{~L} / \mathrm{kg}$ in patients undergoing hemodialysis. ${ }^{1,9}$ Finally, vancomycin is characterized by a rebound phenomenon, whereby the serum concentration of the drug increases after hemodialysis, as a result of the drug shifting from the peripheral to the central compartment. . $11-14^{-14}$

The high prevalence of MRSA has led to widespread use of vancomycin, with a target trough serum concentration of $5-10 \mathrm{mg} / \mathrm{L} .^{37,15,16}$ This practice has resulted in the emergence of less susceptible strains of MRSA., ${ }^{3,15,16}$ In addition, recent studies have shown a correlation between vancomycin trough serum concentration of $5-10 \mathrm{mg} / \mathrm{L}$ and failure to eradicate MRSA from tissues surrounding the dialysis access. ${ }^{715-18}$ In fact, recent guidelines have recommended that the trough serum concentration of vancomycin should be between 15 and 20 $\mathrm{mg} / \mathrm{L}$ for patients with bacteremia, endocarditis, osteomyelitis, meningitis, or hospital-acquired pneumonia., ${ }^{3,19,20}$ However, these recommendations are intended for patients with normal kidney function and may not be appropriate in the setting of severe kidney disease because of the prolonged half-life of the drug in this patient population. ${ }^{1}$ In addition, measuring the serum concentration of vancomycin within 1 to $2 \mathrm{~h}$ after hemodialysis could be misleading because of the rebound phenomenon. As such, the serum concentration of vancomycin before hemodialysis (i.e., the pre-hemodialysis concentration) may be an appropriate alternative to trough serum concentration. ${ }^{1,12}$ In fact, in 2009, the St John Hospital and Medical
Center in Detroit, Michigan, advised clinicians to target a prehemodialysis serum concentration of vancomycin of 15-20 $\mathrm{mg} / \mathrm{L}$ for all hemodialysis patients requiring vancomycin therapy.

The current guidelines suggest a loading dose of 15-20 $\mathrm{mg} / \mathrm{kg}$ actual body weight $(25-30 \mathrm{mg} / \mathrm{kg}$ for seriously ill patients) to attain the advocated trough concentration of 15-20 mg/L., ${ }^{3,20}$ However, little is known about the loading dose required to attain the optimal therapeutic pre-hemodialysis serum concentration in hemodialysis patients. This study was undertaken to explore the optimal loading dose strategy for vancomycin in patients with stage 5 chronic kidney disease who are undergoing hemodialysis and to examine the determinants of pre-hemodialysis serum concentration of the drug in these patients.

\section{METHODS}

\section{Study Design}

A prospective observational cohort study was conducted with a convenience sample of 81 patients with stage 5 chronic kidney disease who were admitted to the St John Hospital and Medical Center (a 772-bed teaching hospital in east Detroit, Michigan) for treatment of infection from January to June 2010. Post hoc power analysis showed that this sample size $(n)$ was sufficient to avoid type II error, according to the criteria of Tabachnick and Fidell ${ }^{21}$ (i.e., $n \geq 50+8 m$, where $m$ is the number of independent variables in the model $[m=3]) .{ }^{21}$ Patients were deemed eligible for inclusion if they were at least 18 years of age; had an established diagnosis of stage 5 chronic kidney disease and were undergoing hemodialysis before admission to hospital; were undergoing 3 sessions of intermittent hemodialysis per week, with each session lasting 3 to $5 \mathrm{~h}$; had received at least one dose of vancomycin (i.e., the loading dose) upon admission; and had serum concentration of vancomycin measured before the first scheduled post-admission hemodialysis session. Pregnant women were excluded. The study was approved by the institutional review board at St John Hospital and Medical Center in Detroit.

\section{Vancomycin Dosing}

A loading dose of vancomycin was administered to eligible patients with suspected or confirmed MRSA infection upon their admission to hospital. The clinical pharmacists in the hospital were advised to use a preset chart (shown in Table 1) to determine the appropriate loading dose, according to the patient's body weight. For any patient who received a loading dose lower than that recommended in Table 1, either before or at the time of admission to hospital, the clinical pharmacists were encouraged but not required to order a correction (extra) dose as soon as possible, to ensure that dosing conformed with recommendations. 
Table 1. Scale for Determining Loading Dose of Vancomycin

\begin{tabular}{lc} 
Weight* $(\mathbf{k g})$ & Loading Doset $(\mathbf{m g})$ \\
\hline $40-49$ & 750 \\
$50-64$ & 1000 \\
$65-78$ & 1250 \\
$79-92$ & 1500 \\
$93-107$ & 1750 \\
$108-121$ & 2000 \\
$122-135$ & 2250 \\
$136-150$ & 2500 \\
$151-164$ & 2750 \\
$165-178$ & 3000 \\
$179-192$ & 3250 \\
$193-200$ & 3500 \\
\hline
\end{tabular}

${ }^{\star}$ The patient's body weight was rounded up or down to the nearest kilogram.

†The loading doses shown here are based on body weight multiplied by $17.5 \mathrm{mg}$ (midpoint in the target range of $15-20 \mathrm{mg} / \mathrm{kg}$ ), with the product being rounded up or down to the nearest 250 mg. For example, according to this formula, a 78-kg patient should receive a loading dose of $1365 \mathrm{mg}$; rounding to the nearest $250 \mathrm{mg}$ yields a loading dose of $1250 \mathrm{mg}$. Similarly, according to the formula, a 79-kg patient should receive a loading dose of $1382.5 \mathrm{mg}$; rounding to the nearest $250 \mathrm{mg}$ yields a loading dose of $1500 \mathrm{mg}$. The clinical pharmacists were encouraged to use this chart to determine the appropriate loading dose for the patient's body weight.

\section{Definition of Variables}

The patient's body weight used for determining the loading dose was based on the average of wet weight (recorded at hospital admission) and dry weight (obtained from the patient's previous electronic records). The volume of distribution (L/kg) was calculated by dividing the loading dose $(\mathrm{mg})$ by the product of body weight $(\mathrm{kg})$ and measured pre-hemodialysis serum concentration $(\mathrm{mg} / \mathrm{L})$. Elapsed time was defined as the approximate period between administration of the vancomycin dose (i.e., end of the infusion) and measurement of prehemodialysis serum concentration. For patients who received a correction dose, the elapsed time was the time between administration of the correction dose (i.e., end of the infusion) and measurement of pre-hemodialysis serum concentration.

\section{Data Analysis}

The data were analyzed using SPSS, version 20.0 (IBM). Basic descriptive statistics were used to describe the sample characteristics. Pearson moment correlations and Student's $t$ test were used to identify the unadjusted associations between each of the study variables and the outcome variable (i.e., measured pre-hemodialysis serum concentration). Multivariate stepwise linear regression was then performed to examine independent associations of the variables with the measured prehemodialysis serum concentration. Variables were entered into the regression model on the basis of a liberal $\alpha$ value $(\leq 0.25)$ to maximize the parsimony of the model and avoid the elimination of potentially important variables. ${ }^{22}$ The loading doses administered were divided into 3 categories $(<15 \mathrm{mg} / \mathrm{kg}$, $15-20 \mathrm{mg} / \mathrm{kg}$, and $>20 \mathrm{mg} / \mathrm{kg}$ ). The categorical forms of the loading dose and the measured pre-hemodialysis concentrations were cross-tabulated to explore which loading dose was likely to yield the optimal serum concentration of vancomycin. Statistical significance was established using a 2-tailed $\alpha$ of 0.05 .

\section{RESULTS}

\section{Sample and Dialysis Characteristics}

The mean age of the 81 participants was 57.8 years (standard deviation [SD] 16.1), and 46 participants (57\%) were women. The sample was composed of 65 African Americans (80\%) and 16 whites (20\%). Most of the patients (74 [91\%]) had hypertension, whereas only $7(9 \%)$ had cancer. More than half (50 [62\%]) had type 1 or type 2 diabetes mellitus, and 59 (73\%) had heart disease. Average weight was $82.9 \mathrm{~kg}$ (SD $26.45 \mathrm{~kg}$, range $37-166 \mathrm{~kg}$ ), and average height was $168.5 \mathrm{~cm}$ (SD $11 \mathrm{~cm}$, range $142-200 \mathrm{~cm}$ ). The majority of patients presented with hemodialysis catheter- or graft-related bacteremia (49 [60\%]), cellulitis (10 [12\%]), or pneumonia (8 [10\%]). None of the patients had severe sepsis or septic shock, and none had stayed in the intensive care unit.

The average dialysate flow rate was $795 \mathrm{~mL} / \mathrm{min}$ (SD 26.9 $\mathrm{mL} / \mathrm{min}$, range $600-800 \mathrm{~mL} / \mathrm{min}$ ), the average duration of dialysis was $3.43 \mathrm{~h}$ (SD $0.34 \mathrm{~h}$, range $2.5-5.0 \mathrm{~h}$ ), and the average blood flow rate was $362 \mathrm{~mL} / \mathrm{min}$ (SD $44.0 \mathrm{~mL} / \mathrm{min}$, range $250-450 \mathrm{~mL} / \mathrm{min}$ ). The mean loading dose of vancomycin administered was $1500 \mathrm{mg}$ (SD $450 \mathrm{mg}$, range 1000-3000 mg), yielding a mean weight-based loading dose of $18.6 \mathrm{mg} / \mathrm{kg}$ (SD $4.1 \mathrm{mg} / \mathrm{kg}$, range $6.1-31.9 \mathrm{mg} / \mathrm{kg}$ ). The mean elapsed time (i.e., between end of loading dose infusion and pre-hemodialysis measurement of vancomycin serum concentration) was $27.9 \mathrm{~h}$ (SD $17.4 \mathrm{~h}$, median $24 \mathrm{~h}$ ). The average volume of distribution for vancomycin was $0.90 \mathrm{~L} / \mathrm{kg}$ (SD $0.27 \mathrm{~L} / \mathrm{kg}$, range $0.38-1.55 \mathrm{~L} / \mathrm{kg}$ ). The mean pre-hemodialysis serum concentration of vancomycin was $22.1 \mathrm{mg} / \mathrm{L}$ (SD 4.9 mg/L, median $21.7 \mathrm{mg} / \mathrm{L}$ ). Only 29 (36\%) of the patients received a correction dose of vancomycin.

\section{Vancomycin Dosing Analysis}

The bivariate correlations indicated that pre-hemodialysis serum concentration was negatively correlated with age $(r=$ $-0.405, p<0.001$ ) and elapsed time between administration of the loading dose and pre-hemodialysis measurement of serum concentration $(r=-0.291, p=0.008)$. Conversely, prehemodialysis serum concentration was positively correlated with weight-based loading dose $(\mathrm{mg} / \mathrm{kg})(r=0.407, p<0.001)$. 
No association was found between the pre-hemodialysis serum concentration and weight $(r=0.089, p=0.43)$ or body mass index $(r=0.085, p=0.45)$. Pre-hemodialysis serum concentration was not significantly associated with any of the demographic or infection variables outlined in Table 2.

Linear regression analysis suggested an independent association between each of the 3 variables in the model and pre-hemodialysis serum concentration (Table 3). Specifically, age was the most significant predictor $(\beta=-0.358, p<0.001)$, followed by weight-based loading dose $(\mathrm{mg} / \mathrm{kg})(\beta=0.293$, $p=0.003$ ) and elapsed time between administration of the loading dose and pre-hemodialysis measurement of vancomycin serum concentration $(\beta=-0.247, p=0.011)$. Together, the 3 independent predictors in the model explained
$43.1 \%$ of the total variance in the outcome variable.

Table 4 displays the cross-tabulation between weightbased loading dose $(\mathrm{mg} / \mathrm{kg})$ and pre-hemodialysis serum concentration $(\mathrm{mg} / \mathrm{L})$. For 14 of the 24 patients who achieved the recommended pre-hemodialysis serum concentration (15-20 mg/L), the loading dose fell between 15 and $20 \mathrm{mg} / \mathrm{kg}$. Furthermore, of the 50 patients who received a loading dose of 15-20 mg, 26 patients achieved a pre-hemodialysis concentration between 15 and $25 \mathrm{mg} / \mathrm{L}$, and 36 patients achieved a pre-hemodialysis concentration between 15 and $30 \mathrm{mg} / \mathrm{L}$. Only 4 of the 21 patients who received a loading dose exceeding $20 \mathrm{mg} / \mathrm{kg}$ achieved the recommended pre-hemodialysis serum concentration of $15-20 \mathrm{mg} / \mathrm{L}$.

Table 2. Pre-hemodialysis Serum Concentration of Vancomycin in Relation to Demographic Characteristics

\begin{tabular}{|c|c|c|c|c|}
\hline \multirow[b]{2}{*}{ Variable } & \multicolumn{2}{|c|}{ Pre-hemodialysis Serum Concentration (mg/L) } & \multirow[b]{2}{*}{ Test Statistic } & \multirow[b]{2}{*}{$p$ value* } \\
\hline & Mean \pm SD & Range & & \\
\hline Sex & & & $t=0.446$ & 0.66 \\
\hline Male & $21.80 \pm 7.45$ & $8.8-43.2$ & & \\
\hline Female & $22.64 \pm 9.00$ & $8.7-48.3$ & & \\
\hline Racial background & & & $t=0.013$ & 0.99 \\
\hline White & $22.25 \pm 8.83$ & $15.1-44.0$ & & \\
\hline African American & $22.28 \pm 8.27$ & $8.7-48.3$ & & \\
\hline Hypertension & & & $t=0.060$ & 0.95 \\
\hline Yes & $22.26 \pm 8.28$ & $8.7-48.3$ & & \\
\hline No & $22.46 \pm 9.44$ & $12.1-40.6$ & & \\
\hline Diabetes mellitus & & & $t=0.491$ & 0.62 \\
\hline Yes & $21.92 \pm 7.78$ & $8.7-44.0$ & & \\
\hline No & $22.86 \pm 9.26$ & $10.3-48.3$ & & \\
\hline Heart disease & & & $t=0.374$ & 0.71 \\
\hline Yes & $21.06 \pm 8.63$ & $8.7-48.3$ & & \\
\hline No & $22.85 \pm 7.61$ & $11.5-37.5$ & & \\
\hline Cancer & & & $t=1.003$ & 0.32 \\
\hline Yes & $19.26 \pm 6.61$ & $10.3-30.5$ & & \\
\hline No & $22.56 \pm 8.45$ & $8.7-48.3$ & & \\
\hline Type of infection & & & $F=0.846$ & 0.47 \\
\hline Bacteremia & $22.53 \pm 8.96$ & $8.7-48.3$ & & \\
\hline Cellulitis & $18.89 \pm 5.44$ & $8.8-24.6$ & & \\
\hline Pneumonia & $25.00 \pm 8.11$ & $13.9-40.6$ & & \\
\hline Other & $22.24 \pm 24.00$ & $12.1-36.2$ & & \\
\hline
\end{tabular}

$F=F$ ratio for analysis of variance, $\mathrm{SD}=$ standard deviation, $t=$ test result for Student $t$ test. .

*Probability of statistical significance at $\alpha=0.05$.

Table 3. Results of Linear Regression Analysis Demonstrating Independent Associations with Pre-hemodialysis Serum Concentration of Vancomycin*

\begin{tabular}{lccrrr} 
Variable & $\boldsymbol{B}$ & SE & $\boldsymbol{B}$ & $\boldsymbol{t}$ & $\boldsymbol{\boldsymbol { P }}$ \\
\hline Age, in years $(a)$ & -0.185 & 0.049 & -0.358 & -3.779 & $<0.001$ \\
\hline Elapsed time, + in hours $(b)$ & -0.118 & 0.045 & -0.247 & -2.599 & 0.011 \\
\hline Loading dose, in mg/kg (c) & 0.592 & 0.195 & 0.293 & 3.031 & 0.003 \\
\hline B
\end{tabular}

$B=$ unstandardized regression coefficient, $\mathrm{SE}=$ standard error of the coefficient, $B=$ standardized regression coefficient.

*The constant for the model was 25.259, and the predictive equation for measured serum concentration of vancomycin ( $Y$ ) was as follows: $Y=25.259+-0.185 a-0.118 b+0.592 c$, where $a, b$, and $c$ represent the 3 variables in column 1 . tElapsed time is the time between the end of infusion of the loading dose and measurement of pre-hemodialysis serum concentration of vancomycin. 
This single copy is for your personal, non-commercial use only.

For permission to reprint multiple copies or to order presentation-ready copies for distribution, contact CJHP at cjhpedit@cshp.ca

Table 4. Cross-tabulation between Measured Pre-hemodialysis Serum Concentration of Vancomycin and Weight-Based Loading Dose Administered

\begin{tabular}{|c|c|c|c|c|c|c|c|}
\hline \multirow{2}{*}{$\begin{array}{l}\text { Weight-Based } \\
\text { Loading Dose* }\end{array}$} & \multicolumn{7}{|c|}{ Measured Pre-hemodialysis Serum Concentration of Vancomycin (mg/L) } \\
\hline & $<10$ & 10-14.99 & $15-20$ & $20.01-25$ & $25.01-30$ & $>30$ & Total \\
\hline \multicolumn{8}{|l|}{$<15 \mathrm{mg} / \mathrm{kg}$} \\
\hline No. of patientst & 1 & 3 & 6 & 0 & 0 & 0 & 10 \\
\hline Mean \pm SD $\neq$ & 8.7 & $13.5 \pm 1.74$ & $15.97 \pm 0.7$ & NA & NA & NA & $14.5 \pm 2.54$ \\
\hline Range & NA & $11.5-14.6$ & $15.1-17.2$ & NA & NA & NA & 8.7-17.2 \\
\hline \multicolumn{8}{|l|}{$15-20 \mathrm{mg} / \mathrm{kg}$} \\
\hline No. of patientst & 1 & 8 & 14 & 12 & 10 & 5 & 50 \\
\hline Mean \pm SD $\neq$ & 8.8 & $12.7 \pm 1.23$ & $17.74 \pm 1.23$ & $22.56 \pm 1.68$ & $27.31 \pm 1.70$ & $39.60 \pm 6.16$ & $22.01 \pm 8.07$ \\
\hline Range & NA & $10.3-14.1$ & $15.8-19.6$ & $20.5-25.0$ & $25.3-30.0$ & $32.7-48.3$ & $8.8-48.3$ \\
\hline \multicolumn{8}{|l|}{$>20 \mathrm{mg} / \mathrm{kg}$} \\
\hline No. of patientst & 0 & 0 & 4 & 7 & 3 & 7 & 21 \\
\hline Mean \pm SD $\ddagger$ & NA & NA & $17.25 \pm 1.48$ & $22.07 \pm 1.75$ & $27.2 \pm 0.36$ & $36.22 \pm 4.61$ & $26.61 \pm 8.05$ \\
\hline Range & NA & NA & $15.3-18.5$ & $20.3-24.2$ & 26.9-27.6 & $30.5-44.0$ & $15.3-44.0$ \\
\hline \multicolumn{8}{|l|}{ Total } \\
\hline No. of patients† & 2 & 11 & 24 & 19 & 13 & 12 & 81 \\
\hline Mean \pm SD $\neq$ & $8.75 \pm 0.07$ & $12.92 \pm 1.39$ & $17.22 \pm 1.35$ & $22.38 \pm 1.67$ & $27.29 \pm 1.48$ & $37.63 \pm 5.33$ & $22.28 \pm 8.33$ \\
\hline Range & $8.7-8.8$ & $10.3-14.6$ & 15.1-19.6 & $20.3-25.0$ & $25.3-30.0$ & $30.5-48.3$ & $8.7-48.3$ \\
\hline
\end{tabular}

$\mathrm{NA}=$ not applicable, SD = standard deviation.

*The mean loading dose \pm SD was $12.25 \pm 2.38$ for patients who received a loading dose of less than $15 \mathrm{mg} / \mathrm{kg}, 17.65 \pm 1.56$ for those who received $15-20 \mathrm{mg} / \mathrm{kg}$, and $23.91 \pm 2.68$ for those who received more than $20 \mathrm{mg} / \mathrm{kg}$.

†Number of patients who achieved the stated serum concentration of vancomycin.

¥Mean and SD values displayed in the table represent the pre-hemodialysis serum concentration of vancomycin (mg/L), categorized by loading dose and measured serum concentration.

\section{DISCUSSION}

The findings reported here suggest a linear relationship between weight-based loading dose of vancomycin $(\mathrm{mg} / \mathrm{kg})$ and pre-hemodialysis serum concentration. Although this finding was unsurprising, it was unique with regard to certain aspects of the approach to vancomycin dosing and the nature of the hemodialysis setting. Previous investigators have used various dosing strategies in attempts to determine the optimal approach to vancomycin dosing in hemodialysis patients. However, most of these strategies were implemented in outpatient dialysis centres, with vancomycin being infused over the final period of the hemodialysis session. Although this approach saves time, it often results in dialysis of part of the vancomycin dose. For example, Ariano and others ${ }^{14}$ advocated a loading dose of $1 \mathrm{~g}$, administered over the final hour of hemodialysis, followed by $500-\mathrm{mg}$ maintenance doses. This strategy yielded a pre-hemodialysis serum concentration of $5-20 \mathrm{mg} / \mathrm{L}$ in $96 \%$ of patients in that study. Similarly, Vandecasteele and others ${ }^{7}$ concluded that a loading dose of $20 \mathrm{mg} / \mathrm{kg}$ administered during the last $15-120 \mathrm{~min}$ of hemodialysis led to a subtherapeutic pre-hemodialysis serum concentration $(14.8 \pm 4.3 \mathrm{mg} / \mathrm{L})$. The results in both of these studies might be attributable to the intradialysis infusion of vancomycin. Barth and DeVincenzo ${ }^{17}$ administered a loading dose of $20 \mathrm{mg} / \mathrm{kg}$ after hemodialysis was complete, an approach that resulted in a pre-hemodialysis serum concentration of
$10-25 \mathrm{mg} / \mathrm{L}$. Similarly, Pai and Pai ${ }^{10}$ retrospectively determined that a loading dose of $1 \mathrm{~g}$ administered after completion of hemodialysis achieved pre-hemodialysis serum concentrations between 5 and $20 \mathrm{mg} / \mathrm{L}$ in $93 \%$ of patients. Finally, in a recently published retrospective study involving hospitalized hemodialysis patients, Brown and others ${ }^{23}$ demonstrated that a loading dose of $15 \mathrm{mg} / \mathrm{kg}$ administered after the end of dialysis achieved a mean pre-hemodialysis serum concentration of $19 \pm$ $7.1 \mathrm{mg} / \mathrm{L}$, except for patients over 65 years of age. Interestingly, the strategies described in all of these previous studies were insufficient to meet the new guideline recommendations. ${ }^{319,20}$

Unlike the study reported here, the aforementioned studies took place before publication of the recent guidelines, ${ }^{3,20}$ which recommend trough serum concentrations of at least $15 \mathrm{mg} / \mathrm{L}$ to achieve the target pharmacodynamic outcome for ratio of area under the curve to minimum inhibitory concentration (AUC/MIC) of greater than 400. Achievement of this ratio value is required to treat complicated infections, especially when the MIC of MRSA is $1 \mathrm{mg} / \mathrm{L}$. $^{1,3,423}$ Although hemodialysis patients were included in the studies supporting these recommendations, the relationship between AUC/MIC and pre-hemodialysis serum concentration has not been validated in a large cohort study. ${ }^{724}$ Notably, Vandecasteele and others ${ }^{7}$ were able to establish a linear correlation between AUC/MIC and pre-hemodialysis vancomycin serum concentration by means of a mathematical simulation based on their findings. More specifically, pre-hemodialysis serum concentrations of 10 , 
15, and $20 \mathrm{mg} / \mathrm{L}$ corresponded to calculated 24-h AUC/MIC values of 269, 404, and 538, respectively, for bacteria with MIC of $1 \mathrm{mg} / \mathrm{L}$. $^{7}$ Consequently a pre-hemodialysis serum concentration of $15-20 \mathrm{mg} / \mathrm{L}$ or higher would be more appropriate to eradicate MRSA infections with MIC of $1-2 \mathrm{mg} / \mathrm{L}$.

The findings reported here suggest that the elapsed time between administration of the vancomycin loading dose and measurement of pre-hemodialysis vancomycin serum concentration was an independent predictor of that concentration. Specifically, there was a negative association between these 2 variables. Vandecasteele and others ${ }^{7}$ reported results similar to those of the current study, suggesting that vancomycin serum concentration decreased with increasing time between administration of the drug and measurement of pre-hemodialysis serum concentration. This is an important finding, given that a relatively long time (up to $72 \mathrm{~h}$ ) may elapse between administration of vancomycin and the first scheduled hemodialysis session.

In this study, age was another independent predictor of pre-hemodialysis serum concentration of vancomycin, whereby older age was associated with lower concentration. This finding matches those of Brown and others, ${ }^{23}$ but no other reports were found to suggest or explain such a relationship. Interestingly, the current study and that of Brown and others ${ }^{23}$ were similar with regard to pre-hemodialysis measurement of vancomycin serum concentration after administration of the loading dose. The association between age and pre-hemodialysis serum concentration of vancomycin should be investigated further.

The 3 independent variables in our model explained a total of $43.1 \%$ of the variance in pre-hemodialysis serum concentration. As such, a significant amount of variance remains to be accounted for. Interestingly, other investigators, including Brown and others, ${ }^{23}$ either did not report such data or did not report them clearly. For example, Vandecasteele and others ${ }^{7}$ indicated in their abstract that their model contained 3 variables (pre-hemodialysis serum concentration of vancomycin, dry body weight, and period to the next dialysis session) that explained $94.6 \%$ of the observed variance of the outcome, but the outcome was not specified and information about this finding was not mentioned in the main text of the article. Furthermore, these authors were mostly interested in measuring the post-hemodialysis serum concentration based on their knowledge of the maintenance dose. Thus, their model and outcome variable were conceptually different from ours, and the percentage of variance explained in the current study should not be compared with that of Vandecasteele and others.? Additional studies are needed to identify variables explaining the relatively large percentage of unexplained variance in pre-hemodialysis serum concentration of vancomycin.

The cross-tabulation of loading doses and pre-hemodialysis serum concentration (Table 4) indicated that patients who received a loading dose between 15 and $20 \mathrm{mg} / \mathrm{kg}$ were more likely to achieve a serum concentration of the drug within the acceptable range $(15-20 \mathrm{mg} / \mathrm{L})$. In fact, very few of these patients had a serum concentration less than $15 \mathrm{mg} / \mathrm{L}$ or exceeding $30 \mathrm{mg} / \mathrm{L}$. However, patients who received a loading dose above $20 \mathrm{mg} / \mathrm{kg}$ were more likely to attain drug serum concentrations exceeding the target range of $15-20 \mathrm{mg} / \mathrm{L}$, with a smaller percentage of patients reaching a serum concentration within that target range. In fact, only 4 of the 21 patients with a loading dose above $20 \mathrm{mg} / \mathrm{kg}$ had a pre-hemodialysis serum concentration between 15 and $20 \mathrm{mg} / \mathrm{L}$, where 7 of these patients had a serum concentration exceeding $30 \mathrm{mg} / \mathrm{L}$. These findings may indicate that a loading dose of $15-20 \mathrm{mg} / \mathrm{kg}$ is optimal with regard to attaining the therapeutic pre-hemodialysis serum concentration of $15-20 \mathrm{mg} / \mathrm{L}$. However, given the lack of strict guidelines on what constitutes an optimal pre-hemodialysis concentration and given that some clinicians may argue that a pre-hemodialysis concentration up to 30 $\mathrm{mg} / \mathrm{L}$ is acceptable, our findings can be interpreted as demonstrating that a loading dose of $15-20 \mathrm{mg} / \mathrm{kg}$ is optimal to yield a pre-hemodialysis concentration of $15-25 \mathrm{mg} / \mathrm{L}$ or even $30 \mathrm{mg} / \mathrm{L}$.

\section{Limitations}

The limitations of this study, which must be considered before any sweeping conclusions are drawn from the findings, include the fact that elapsed time was measured from the last administered dose of vancomycin, either the loading dose or the correction dose (if the patient received one). Second, data were collected for patients with established hemodialysis therapy, without consideration of any residual renal function. Third, given the observational cohort design of this study, no data were collected on the duration of dialysis before hospital admission. Finally, the patient's body weight (for purposes of weight-based dosing) was calculated as the average of wet weight (at hospital admission) and dry weight (obtained from the patient's previous electronic records).

\section{CONCLUSIONS}

The findings of this study indicate that a vancomycin loading dose of $15-20 \mathrm{mg} / \mathrm{kg}$ actual body weight is likely to yield an optimal pre-hemodialysis serum concentration at a median elapsed time of $24 \mathrm{~h}$. The findings also suggest that, in addition to the loading dose, the patient's age and the elapsed time between administration of the loading dose and measurement of pre-hemodialysis serum concentration also influence the pre-hemodialysis serum concentration. Although the limitations described above preclude sweeping conclusions, they do mimic the real-life situations that clinicians may face. In addition, the findings provide important insights about factors 
influencing the ability to achieve therapeutic vancomycin serum concentration and the loading dose that is most commonly associated with attainment of such targets.

\section{References}

1. Vandecasteele SJ, De Vriese AS. Vancomycin dosing in patients on intermittent hemodialysis. Semin Dial 2011;24(1):50-55.

2. Zoer J, Schrander-van der Meer AM, van Dorp WT. Dosage recommendation of vancomycin during haemodialysis with highly permeable membranes. Pharm World Sci 1997;19(4):191-196.

3. Rybak M, Lomaestro B, Rotschafer JC, Moellering R Jr, Craig W, Billeter $\mathrm{M}$, et al. Therapeutic monitoring of vancomycin in adult patients: a consensus review of the American Society of Health-System Pharmacists, the Infectious Diseases Society of America, and the Society of Infectious Diseases Pharmacists. Am J Health Syst Pharm 2009;66(1):82-98. Erratum in: Am J Health Syst Pharm 2009;66(10):887.

4. Vandecasteele SJ, De Vriese AS. Recent changes in vancomycin use in renal failure. Kidney Int 2010;77(9):760-764.

5. Jones RN. Key considerations in the treatment of complicated staphylococcal infections. Clin Microbiol Infect 2008;14 Suppl 2:3-9.

6. Pallotta KE, Manley HJ. Vancomycin use in patients requiring hemodialysis: a literature review. Semin Dial 2008;21(1):63-70.

7. Vandecasteele SJ, De Bacquer D, De Vriese AS. Implementation of a dose calculator for vancomycin to achieve target trough levels of 15-20 microg/mL in persons undergoing hemodialysis. Clin Infect Dis 2011;53(2):124-129.

8. Crawford BS, Largen RF, Walton T, Doran JJ. Once-weekly vancomycin for patients receiving high-flux hemodialysis. Am J Health Syst Pharm 2008;65(13):1248-1253.

9. Gilbert B, Robbins P, Livornese LL Jr. Use of antibacterial agents in renal failure. Med Clin North Am 2011;95(4):677-702.

10. Pai AB, Pai MP. Vancomycin dosing in high flux hemodialysis: a limitedsampling algorithm. Am J Health Syst Pharm 2004;61(17):1812-1816.

11. Pollard TA, Lampasona V, Akkerman S, Tom K, Hooks MA, Mullins RE, et al. Vancomycin redistribution: dosing recommendations following high-flux hemodialysis. Kidney Int 1994;45(1):232-237.

12. Launay-Vacher V, Izzedine H, Mercadal L, Deray G. Clinical review: use of vancomycin in haemodialysis patients. Crit Care 2002;6(4):313-316.

13. Touchette MA, Patel RV, Anandan JV, Dumler F, Zarowitz BJ. Vancomycin removal by high-flux polysulfone hemodialysis membranes in critically ill patients with end-stage renal disease. Am J Kidney Dis 1995;26(3):469-474.

14. Ariano RE, Fine A, Sitar DS, Rexrode S, Zelenitsky SA. Adequacy of a vancomycin dosing regimen in patients receiving high-flux hemodialysis. Am J Kidney Dis 2005;46(4):681-687.

15. Gould IM. Clinical relevance of increasing glycopeptide MICs against Staphylococcus aureus. Int J Antimicrob Agents 2008;31 Suppl 2:1-9.

16. Kullar R, Davis SL, Taylor TN, Kaye KS, Rybak MJ. Effects of targeting higher vancomycin trough levels on clinical outcomes and costs in a matched patient cohort. Pharmacotherapy 2012;32(3):195-201.
17. Barth RH, DeVincenzo N. Use of vancomycin in high-flux hemodialysis: experience with 130 courses of therapy. Kidney Int 1996;50(3):929-936.

18. Steinkraus G, White R, Friedrich L. Vancomycin MIC creep in nonvancomycin-intermediate Staphylococcus aureus (VISA), vancomycinsusceptible clinical methicillin-resistant $S$. aureus (MRSA) blood isolates from 2001-05. J Antimicrob Chemother 2007;60(4):788-794.

19. American Thoracic Society; Infectious Diseases Society of America. Guidelines for the management of adults with hospital-acquired, ventilatorassociated, and healthcare-associated pneumonia. Am J Respir Crit Care Med 2005;171(4):388-416.

20. Liu C, Bayer A, Cosgrove SE, Daum RS, Fridkin SK, Gorwitz RJ, et al. Clinical practice guidelines by the Infectious Diseases Society of America for the treatment of methicillin-resistant Staphylococcus aureus infections in adults and children. Clin Infect Dis 2011;52:e18-e55. Erratum in: Clin Infect Dis 2011;53(3):319.

21. Tabachnick BG, Fidell L. Using multivariate statistics. 4th ed. Boston (MA): Allyn \& Bacon; 2001.

22. Hosmer DW, Lemeshow S. Applied logistic regression. New York (NY): Wiley; 1989.

23. Brown M, Polisetty R, Gracely EJ, Cuhaci B, Schlecht HP. Weight-based loading of vancomycin in patients on hemodialysis. Clin Infect Dis 2011;53(2):164-166.

24. Zelenitsky SA, Ariano RE, McCrae ML, Vercaigne LM. Initial vancomycin dosing protocol to achieve therapeutic serum concentrations in patients undergoing hemodialysis. Clin Infect Dis 2012;55(4):527-533.

Wasim S El Nekidy, PharmD, BCPS, is a Clinical Pharmacy Specialist with the Department of Pharmacy and the Department of Nephrology, HotelDieu Grace Hospital, Windsor, Ontario.

Maher M El-Masri, PhD, RN, is a Professor and Research Leadership Chair, Faculty of Nursing, University of Windsor, Windsor, Ontario.

Greg S Umstead, PharmD, is a Clinical Pharmacy Specialist, St John Hospital \& Medical Center, Detroit, Michigan.

Michelle Dehoorne-Smith, PharmD, is the Manager of Patient Care Services, St John Hospital \& Medical Center, Detroit, Michigan.

\section{Address correspondence to:}

Dr Wasim S El Nekidy

Department of Pharmacy

Hotel-Dieu Grace Hospital

1030 Ouellette Avenue

Windsor ON N9A 1E1

e-mail: wasim.elnekidy@hdgh.org

\section{Acknowledgements}

We would like to thank the members of the Department of Pharmacy at St John Hospital and Medical Center in Detroit for the provision of medication-related care to the patients included in this study. 